\title{
BALTHAZAR GIBERT, La Rhétorique ou les règles de l'éloquence
}

\section{Paola Sosso}

\section{(2) OpenEdition}

\section{Journals}

\section{Edizione digitale}

URL: http://journals.openedition.org/studifrancesi/33252

DOI: 10.4000/studifrancesi.33252

ISSN: 2427-5856

\section{Editore}

Rosenberg \& Sellier

\section{Edizione cartacea}

Data di pubblicazione: 1 décembre 2005

Paginazione: 645

ISSN: 0039-2944

\section{Notizia bibliografica digitale}

Paola Sosso, «Balthazar gibert, La Rhétorique ou les règles de l'éloquence», Studi Francesi [Online], 147 (XLX | III) | 2005, online dal 01 novembre 2015, consultato il 18 avril 2021. URL: http://

journals.openedition.org/studifrancesi/33252 ; DOI: https://doi.org/10.4000/studifrancesi.33252

Questo documento è stato generato automaticamente il 18 avril 2021.

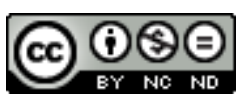

Studi Francesi è distribuita con Licenza Creative Commons Attribuzione - Non commerciale - Non opere derivate 4.0 Internazionale. 


\title{
BALTHAZAR GIBERT, La Rhétorique ou les règles de l'éloquence
}

\author{
Paola Sosso
}

\section{NOTIZIA}

BALTHAZAR GIBERT, La Rhétorique ou les règles de l'éloquence, édition critique par Samy Ben MESSAOUD, Paris, Champion, 2004, pp. 698.

1 Questo trattato, che gli amici di Gibert tanto sollecitarono, uscì per la prima volta nel 1730 e venne ripubblicato nel 1749 e nel 1766. Letto ed apprezzato nell'Ancien Régime (l'Encyclopédie ne elogia le qualità didattiche), viene qui presentato con un'ampia introduzione che offre alcuni chiarimenti riguardo la genesi del testo. Amico intimo di Boileau, professore di d'Alembert, rettore dell'Università di Parigi, Balthazar Gibert (1662-1741) era molto noto alla sua epoca. Dopo alcune controversie con François Lamy e Charles Rollin (a queste ultime è dedicata una sezione dell'introduzione), egli pubblicò la Rhétorique, sintesi critica della tradizione retorica: diviso in tre libri, in cui vengono presentate in modo metodico le regole dell'inventio, della dispositio e dell'elocutio, l'ampio volume è seguito da un Abrégé, rapido riassunto del contenuto inserito per scopi didattici. Gli esempi forniti da Gibert sono tratti dai migliori oratori, da Demostene a Eschine a Isocrate, e dai grandi classici (Boileau, Racine, Corneille). Già noto ai contemporanei per i suoi Jugements des savants (1713), storia dei maitres de l'éloquence, Gibert scrisse questo secondo volume per difendere la retorica dagli attacchi provenienti da Goibaud Du Bois e François Lamy e dagli ambienti vicini alla filosofia cartesiana (Edme Pourchot e Henri Lelevel). Commentatore di Sant'Agostino e vicino alle posizioni di Port-Royal, l'autore rimane all'interno della tradizione aristotelica, ma applica le regole della retorica pagana all'eloquenza cristiana, ricorrendo a citazioni tratte da numerosi predicatori, tra cui Fléchier e Massillon. Opera di un erudito, la Rhétorique è un trattato che offre una sintesi di rilievo dell'arte di persuadere e fornisce al contempo l'abbozzo di una lettura pragmatica dell'arte retorica. L'edizione seguita è 
quella del 1730; le note sono a piè di pagina, mentre le Annexes raccolgono due documenti rari: una lettera di Gibert al Journal littéraire del 1715 e un articolo biobibliografico pubblicato nelle Nouvelles ecclésiastiques il 13 maggio 1742. L'elenco dettagliato delle opere di Gibert è seguito da una ricca e precisa bibliografia, dall'indice dei nomi e delle nozioni. 